\title{
PARTISIPASI DAN KONTRIBUSI TENAGA KERJA WANITA PADA USAHA KERIPIK UBI KAYU TERHADAP PENDAPATAN RUMAH TANGGA DI KELURAHAN KULIM KECAMATAN TENAYAN RAYA KOTA PEKANBARU
}

\author{
Participation and Contribution of Female Workers on Cassava Chips Business to \\ Household Income in Kulim Urban District Tenayan Raya Pekanbaru City
}

\author{
Tibrani \\ Fakultas Pertanian Universitas Islam Riau Jl. Kaharuddin Nasution No. 113 Pekanbaru. 28284, Riau \\ Telp: 0761-674681; Fax: 0761-674681 \\ [Diterima: Mei 2016; Disetujui: Juni 2016]
}

\begin{abstract}
The role of female laborers is not only a housewife but also has multiple roles in her family. This study aims to analyze: (1) Characteristics of female labor and business profile of cassava chips, (2) The amount of female worker participation, (3) The amount of female labor contribution to cassava chips business to household income, 4) Factors influencing the participation of female workers in cassava chips business. This research was conducted in Kulim District Tenayan Raya District from January to May 2016 using survey method. The sample of the study was deliberately taken by 33 female workers. The results showed that the average age of female workers was 33 years old, 9 years old with 3 years of work experience and 4 family dependents. Furthermore, female work participation rate (TPK) on cassava chips business is $1.52 \%$ with contribution of female worker earnings to total household income is 33,37\%. F-calculation results show that simultaneously the value of adjusted coefficient R square (R2) 75.20\%. Partially, the factors that influence significantly to participation are age factor, work experience, and woman worker wage at $90 \%$ and $95 \%$ confidence level.
\end{abstract}

Keywords: Cassava Chips, Female Labor, Participation Rate, Contribution of Income

\begin{abstract}
ABSTRAK
Peran tenaga kerja wanita tidak hanya sebagai ibu rumah tangga tetapi juga mempunyai peran ganda dalam keluarganya. Penelitian ini bertujuan untuk menganalisis: (1) Karakteristik tenaga kerja wanita dan profil usaha keripik ubi kayu, (2) Besarnya tingkat partisipasi kerja tenaga kerja wanita, (3) Besarnya kontribusi tenaga kerja wanita pada usaha keripik ubi kayu terhadap pendapatan rumah tangga, (4) Faktor-faktor yang mempengaruh partisipasi tenaga kerja wanita pada usaha keripik ubi kayu. Penelitian ini dilaksanakan di Kelurahan Kulim Kecamatan Tenayan Raya pada bulan Januari hingga Mei Tahun 2016 dengan menggunakan metode survei. Sampel penelitian diambil secara sengaja sebanyak 33 orang tenaga kerja wanita. Hasil penelitian menunjukkan bahwa umur rata-rata tenaga kerja wanita adalah 33 tahun, berpendidikan 9 tahun dengan pengalaman kerja selama 3 tahun dan jumlah tanggungan keluarga 4 orang. Selanjutnya, Tingkat Partisipasi Kerja (TPK) wanita pada usaha keripik ubi kayu sebesar $1,52 \%$ dengan kontribusi pendapatan tenaga kerja wanita terhadap pendapatan total rumah tangga rata-rata sebesar 33,37\%. Hasil perhitungan F-hitung menunjukkan bahwa secara simultan nilai koefesien adjusted $R$ square $\left(R^{2}\right) 75,20 \%$. Secara parsial faktor-faktor yang berpengaruh secara signifikan terhadap partisipasi yaitu faktor umur, pengalaman bekerja, dan upah tenaga kerja wanita pada tingkat kepercayaan $90 \%$ dan $95 \%$.
\end{abstract}

Kata Kunci: Keripik Ubi Kayu, Tenaga Kerja Wanita, Tingkat Partisipasi, Kontribusi Pendapatan.

\section{PENDAHULUAN}

Pembangunan yang sedang dilaksanakan oleh bangsa Indonesia saat ini telah berhasil menempatkan wanita sebagai mitra sejajar pria dan meningkatkan peran aktif wanita dalam proses pembangunan. Namun peningkatan kualitas sumber daya wanita terutama pengembangan diri dan peranannya dalam kehidupan bermasyarakat, berbangsa dan bernegara belum sepenuhnya didukung oleh iklim sosial budaya dan kualitas wanita itu sendiri. Guna meningkatkan kemampuan wanita 
itu perlu lebih dikembangkan melalui peningkatan penguasaan ilmu pengetahuan dan teknologi, keterampilan serta ketahanan mental dan spritual agar dapat lebih memanfaatkan kesempatan berperan aktif disegala bidang kehidupan.

Partisipasi wanita sebagai angkatan tenaga kerja lebih banyak dilihat pada bidang pertanian. Sebagai angkatan tenaga kerja maka wanita merupakan salah satu sumber daya manusia yang dimiliki oleh suatu rumah tangga di suatu daerah. Keterlibatan wanita dalam bekerja di daerah ataupun di pedesaan bukanlah didorong oleh adanya waktu luang ataupun pengembangan bakat, tetapi semata-mata didorong oleh rendahnya tingkat pendapatan suami sehingga untuk membantu kehidupan perekonomian rumah tangga. Maka wanita harus terlibat dalam kegiatan tertentu guna mendapatkan penghasilan yang bisa digunakan untuk mencukupi kebutuhan rumah tangga. Usaha keripik ubi kayu juga merupakan salah satu lapangan kerja yang dapat menyerap tenaga kerja wanita. baik sebagai penghasilan utama maupun penghasilan sampingan.

Usaha pembuatan keripik ubi kayu yang terdapat di Kelurahan Kulim Kecamatan Tenayan Raya merupakan salah satu usaha pembuatan keripik yang berbahan baku ubi kayu. Kegiatan-kegiatannya dilakukan dengan melibatkan tenaga kerja pria dan sebagian besar wanita, dimana para wanita tersebut merupakan ibu rumah tangga di keluarga sekitar daerah tersebut.

Berdasarkan survei pendahuluan yang telah dilakukan bahwa pembuatan keripik ubi kayu pada usaha sedang maupun kecil di Kelurahan Kulim Kecamatan Tenayan Raya ini mampu memberikan dampak positif dalam peningkatan pendapatan bagi usaha keripik ubi kayu dan para tenaga kerja wanita, khususnya wanita yang bekerja membuat keripik ubi kayu untuk meningkatkan pendapatan keluarga mereka. Hal ini terlihat dari semakin banyaknya permintaan konsumen terhadap makanan ringan/snack keripik ubi kayu baik konsumen lokal maupun dari luar daerah yang datang ke tempat usaha untuk membeli kripik ubi kayu.

Usaha-usaha kecil keripik ubi kayu di Kelurahan Kulim telah dimulai sejak lama dan sudah cukup dikenal dengan baik oleh masyarakat. Keunggulan usaha di daerah ini didukung dengan ketersediaan bahan baku ubi kayu yang banyak tersedia didaerah ini. Walaupun usaha keripik ubi kayu ini telah dilaksanakan cukup lama, namun belum banyak yang melakukan penelitian, seberapa besar kontribusi yang di dapat dari usaha ini terhadap pendapatan keluarga para pekerja wanita tersebut, partisipasi yang diberikan oleh pekerja wanita pembuat keripik ubi kayu dan juga faktor apa saja yang mempengaruhi partisipasi.

\section{METODELOGI PENELITIAN}

Penelitian menggunakan metode survei terhadap usaha Keripik Ubi Kayu di Kelurahan Kulim Kecamatan Tenayan Raya Kota Pekanbaru. Penelitian dimulai dari bulan Januari hingga Mei tahun 2016. Pengambilan sampel dilakukan secara sengaja (purposive sampling) dengan cara mengambil 3 orang tenaga kerja wanita disetiap usaha yang dijadikan sampel.

Sampel yang diambil juga berdasarkan kreteria: (1) Tenaga kerja wanita yang sudah menetap atau mempunyai pengalaman bekerja $\geq$ 2 Tahun, (2) Tenaga kerja wanita yang mempunyai suami, (3) Tenaga kerja wanita yang bekerja tidak tergantung pada besar pesanan atau target yang ditetapkan usaha tersebut. Data yang dikumpulkan sebagai bahan analisis terdiri dari data primer dan data sekunder.

\section{Analisis Data \\ Karakteristik Tenaga Kerja Wanita dan Profil Usaha Keripik Ubi Kayu}

Untuk mengetahui karakteristik tenaga kerja wanita pada usaha keripik ubi kayu dianalisis dengan analisis deskriftif kualitatif yang diinterprestasikan dengan menggunakan tabel atau gambar yang didalamnya terdapat umur, pendidikan, pengalaman bekerja dan jumlah tanggungan keluarga.

\section{Tingkat Partisipasi Kerja Wanita}

Untuk menghitung besarnya tingkat partisipasi kerja wanita (TPK) yang bekerja pada usaha keripik ubi kayu di Kelurhana Kulim Kecamatan Tenayan Raya digunakan rumur (Simanjuntak, 1985) yaitu:

TPK Wanita $=\frac{\sum \text { TKWI }}{\sum \text { AKWI }} \times 100 \%$

Keterangan : 
TPK = Tingkat Partisipasi Kerja Wanita pada usaha keripik ubi kayu (\%)

TKWI = Tenaga kerja wanita yang bekerja pada usaha keripik ubi kayu (Orang)

$\mathrm{AKWT}=$ Angkatan Kerja Wanita (Orang)

\section{Kontribusi Pendapatan Tenaga Kerja Wanita}

Untuk menghitung pendapatan total rumah tangga wanita pekerja pembuat keripik ubi kayu maka dihitung dengan menggunakan dengan rumus (Handayani, 2009):

$\mathrm{YT}=\pi+\mathrm{Yj}$.

Keterangan :

$\mathrm{YT}=$ Pendapatan rumah tangga (Rp/Bulan)

$\pi=$ Pendapatan tenaga kerja wanita (Rp/Bulan)

$\mathrm{Yj} \quad=$ Pendapatan suami Rp/Bulan)

Selanjutnya menghitung besarnya kontribusi pendapatan tenaga kerja wanita pembuat keripik ubi kayu dari usaha keripik ubi kayu terhadap pendapatan total rumah tangga dihitung rumus (Handayani, 2009):

$\mathrm{K}=\frac{\mathrm{Yi}}{\mathrm{YT}} \times 100 \%$

Keterangan :

$\mathrm{K}=$ Kontribusi pendapatan tenaga kerja wanita $(\%)$

$\mathrm{Yi}=$ Pendapatan bersih tenaga kerja wanita (Rp)

$\mathrm{YT}=$ Pendapatan total rumah tangga $(\mathrm{Rp})$

\section{Faktor-faktor yang Mempengaruhi Partisipasi Tenaga Kerja Wanita}

Faktor-faktor yang mempengaruhi partisipasi tenaga kerja wanita pada usaha keripik ubi kayu di Kelurahan Kulim Kecamatan Tenayan Raya di analisis dengan statistik regresi linear berganda dengan bantuan SPSS dan Microsoft Excel. Dengan fungsi dapat ditulis: (Suparmoko, 1993)

$\mathrm{Y}=\mathrm{f}(\mathrm{X} 1, \mathrm{X} 2, \mathrm{X} 3, \mathrm{X} 4, \mathrm{X} 5, \mathrm{X} 6)$

Untuk mengetahui pengaruh variabel bebas terhadap variabel terikatnya menurut Sarwono (2006) digunakan rumus analisis regresi linear berganda sebagai berikut:

$\mathrm{Y}=\mathrm{a}+\mathrm{b}_{1} \mathrm{X}_{1}+\mathrm{b}_{2} \mathrm{X}_{2}+\mathrm{b}_{3} \mathrm{X}_{3}+\ldots \ldots . . \mathrm{b}_{\mathrm{n}} \mathrm{X}_{\mathrm{n}}+\mathrm{e} \ldots$
Keterangan :

$\begin{array}{ll}\mathrm{Y} & =\text { Dependen variabel } \\ \mathrm{a} & =\text { Konstanta } \\ \mathrm{b}_{1}, \mathrm{~b}_{2}, \mathrm{~b}_{3, \ldots \ldots \ldots} \mathrm{b}_{\mathrm{n}} & =\text { Koefesien regresi } \\ \mathrm{X}_{1}, \mathrm{X}_{2}, \mathrm{X}_{3}, \ldots \ldots \ldots . \mathrm{X}_{\mathrm{n}} & =\text { Independen variabel }\end{array}$

Fungsi ini bisa diestimasi menggunakan analisis regresi linear berganda dalam logaritma (Gujarati, 1999), dengan cara mentransfer data ke dalam bentuk logaritma, Pengubahan data ke bentuk Ln dimaksudkan untuk meniadakan atau meminimalkan adanya pelanggaran asumsi normalitas dan asumsi klasik regresi. Jika datadata yang digunakan tidak terdistribusi secara normal atau terjadi penyimpangan asumsi klasik maka bisa dilakukan dengan pengubahan ke bentuk Ln ini. Sehingga fungsi menjadi:

Ln $Y=a+b_{1} \ln X_{1}+b_{2} \ln X_{2}+b_{3} \ln X_{3}+b_{4} \ln X_{4}+$ $\mathrm{b}_{5} \ln \mathrm{X}_{5}+\mathrm{b}_{6} \ln \mathrm{X}_{6}+\mathrm{e}$

Keterangan :

Ln Y =Partisipasi tenaga kerja wanita (Jam/bulan)

a $\quad=$ Intersep

$\mathrm{b}_{1}-\mathrm{b}_{2} \quad=$ Kondisi regresi yang akan dihitung

Ln $\mathrm{X}_{1}=$ Umur (Tahun)

Ln $\mathrm{X}_{2}=$ Tingkat pendidikan (Tahun)

Ln $X_{3}=$ Pengalaman bekerja (Tahun)

Ln $\mathrm{X}_{4}=$ Jumlah tanggungan keluarga (Orang)

Ln $\mathrm{X}_{5}=$ Upah (Rp/bulan)

Ln $\mathrm{X}_{6}=$ Total pendapatan keluarga (Rp/bulan)

$\mathrm{e} \quad=$ Variabel pengganggu

Untuk menghitung koefesien regresi parsial digunakan metode kuadrat terkecil dengan meminimumkan jumlah kuadrat kesalahan pengganggu ( $\mathrm{e}=$ minimum). Kemudian untuk mendapatkan standart error koefesien regresi parsial digunakan rumus:

$\mathrm{Se}=\sqrt{\sum \mathrm{ei}^{2} f(\mathrm{n}-\mathrm{k})}$

Keterangan :

$\mathrm{Se}=$ Standart error/simpangan baku

ei $=$ Faktor pengganggu

$\mathrm{n}$ = Banyaknya sampel

$\mathrm{k}=$ Jumlah variabel

Koefesien Determinasi $\left(\mathrm{R}^{2}\right)$ pada intinya mengukur seberapa jauh kemampuan model dalam menerangkan variasi variabel terikat. 
Kelemahan mendasar penggunaan koefesien determinasi adalah bias terhadap jumlah variabel indevenden yang dimasukan kedalam model. Secara bersama-sama ditentukan dengan koefesien determinan berganda $\left(\mathrm{R}^{2}\right)$ dengan kreteria $0 \leq R^{2} \leq 1$. Semakin dekat nilai $R^{2}$ dengan nilai satu, maka makin dekat garis regresi untuk meramalkan $\mathrm{Y}$, kalau $\mathrm{R}^{2}$ sama dengan satu, berarti persentasi variabel bebas terhadap variasi atau naik turunnya variabel terikat sebesar $100 \%$, secara simultan (bersamasama) digunakan rumus (Muhammad 2011) :

$R^{2}=\frac{b 1 \sum X 11 Y+b 2 \sum X 21 Y+b 3 \sum X 31 Y+b 4 \sum X 41 Y+b 5 \sum X 5 i+b 6 X^{\prime} X 61}{\sum Y^{2}}$

Uji statistik F pada dasarnya menunjukkan apakah semua variabel independen atau bebas yang dimasukan dalam model mempunyai pengaruh secara bersama-sama terhadap variabel dependen. Untuk menguji hipotesis secara bersama-sama. Maka digunakan uji $\mathrm{F}$ dengan alfa $5 \%(0,05)$ pada taraf keyakinan 95\% dengan rumus uji $\mathrm{F}$ sebagai berikut (Sudjana, 2001) yaitu:

F hitung $=\frac{\mathrm{R}^{2} /(\mathrm{K}-1)}{\left(1-\mathrm{R}^{2}\right) /\left(\mathrm{n}-\mathrm{K}^{2}\right.}$

Keterangan:

$\mathrm{F}$ = Besarnya $\mathrm{F}$ hitung

$\mathrm{R}^{2}=$ Koefesien regresi

$\mathrm{n}=$ Jumlah sampel

$\mathrm{k}$ = banyaknya variabel yang diamati

Kreteria:

a. F hitung < F tabel, maka tolak Ho dan H1 diterima.

b. F hitung > F tabel, maka terima Ho dan H1 ditolak.

Untuk menguji hipotesis individu secara parsial dengan menggunakan uji T. Dengan membandingkan nilai $t$ hitung dengan $t$ tabel dengan alfa $5 \%(0,05)$ dan tingkat keyakinan 95\%, yaitu dengan rumus (Sinuraya,1995):

$\mathrm{T}$ hitung $=\frac{\beta 1-\beta i}{\mathrm{Se}(\mathrm{bi})}$

Keterangan:

$\beta i=$ Parameter penduga untuk sampel b1 = Nilai bi yang sebenarnya yang terdapat dalam nol

$\mathrm{Se}=$ Simpangan baku $/$ standar error.

Kreteria:

a. $\mathrm{T}$ hitung $\leq \mathrm{T}$ tabel, maka Ho diterima dan H1 ditolak, artinya variabel independen bukan merupakan penjelas variabel dependen.

b. $\mathrm{T}$ hitung $\geq \mathrm{T}$ tabel, maka Ho ditolak dan $\mathrm{H} 1$ di terima, artinya variabel independen merupakan penjelas variabel dependen.

\section{HASIL DAN PEMBAHASAN}

\section{Karakteristik Tenaga Kerja Wanita dan Profil Usaha Keripik Ubi Kayu}

\section{a. Karakteristik Tenaga Kerja Wanita Usaha Keripik Ubi Kayu}

Identitas tenaga kerja wanita menggambarkan kondisi umum dari tenaga kerja wanita usaha keripik ubi kayu yang meliputi: umur tenaga kerja wanita, tingkat pendidikan tenaga kerja wanita, lama bekerja/pengalaman tenaga kerja wanita dan jumlah tanggungan keluarga tenaga kerja wanita tenaga kerja wanita pada usaha keripik ubi kayu di Kelurahan Kulim Kecamatan Tenayan Raya. Rata-rata umur responden yaitu 33 tahun. Lestari et al (1997) menyatakan bahwa usia seseorang berkaitan dengan produktifitas kerja. Apabila sesorang telah mencapai usia lanjut, tenaga untuk bekerja ataupun mengelolah usaha berkurang. Apabila usia seseorang masih dalam usia produktif, maka produktifitasnya dapat ditingkatkan, sehingga hasil pekerjaan yang diperoleh semakin banyak dan pendapatan yang diperoleh dapat meningkat, rata-rata pendidikan yang ditempuh oleh tenaga kerja wanita pada usaha keripik ubi kayu pada tingkat pendidikan setara 9 tahun, rata-rata pengalaman yang ditempuh oleh responden yaitu 3 tahun dan jumlah tanggungan keluarga dengan rata-rata sebanyak 4 orang.

\section{b. Profil Usaha Keripik Ubi Kayu}

Usaha keripik ubi kayu merupakan usaha skala rumah tangga dan mendirikan usahanya rata-rata dengan modal sendiri. Rata-rata usaha keripik ubi kayu ini sudah berdiri dari tahun 1990-an. ada 22 usaha yang didalamnya terdapat 155 orang tenaga kerja yang terdiri dari 
113 tenaga kerja wanita dan 42 tenaga kerja pria. Keripik ubi kayu yang diproduksi oleh pengusaha keripik ubi kayu dalam satu kali produksi rata-rata sebanyak $100-400 \mathrm{~kg}$ ubi kayu dengan perbandingan $100 \mathrm{~kg}$ ubi kayu menjadi $40 \mathrm{~kg}$ keripik ubi kayu sudah siap makan. Usaha keripik proses produksi yang dilakukan oleh pengusaha keripik ubi kayu adalah sebanyak 3 kali setiap satu minggunya atau 12 kali produksi per bulannya.

Sistem pemberian upah kepada para tenaga kerja dengan memberi Rp 400/bungkus kepada para tenaga kerja wanita, semakin banyak yang dibungkus maka semakin banyak upah yang diberikan kepada tenaga kerja tersebut. Terdapat pula sistem pemberian upah dengan menghitung berapa banyak bungkusan keripik ubi kayu dan juga dengan membagi hasil dalam $1 \mathrm{~kg}$ keripik ubi kayu seharga Rp 18.000 dibagi Rp 9600 untuk tenaga kerja dan $\mathrm{Rp} 8400$ untuk pengusaha keripik ubi kayu.Pada pemasaran yang dilakukan para pengusaha yaitu dengan meletakkan hasil produksi keripik ubi kayu di kedai yang telah disediakan oleh pengusaha atau dengan menitipkan keripik ubi kayu di kedaikedai ataupun warung-warung.

\section{Proses Pembuatan Keripik Ubi Kayu yang Dilakukan Tenaga Kerja Wanita}

Proses pembuatan keripik ubi kyu didaerah penelitian ini dilakukan di rumah pengusaha sendiri, sebagai berikut :

1. Persediaan bahan baku: bahan baku didapat dari petani ubi kayu di Jl.Seroja, Jl. Palembang, disepanjang Jl. Km 16 hingga $\mathrm{Km} \mathrm{18,} \mathrm{Jl.} \mathrm{Gunung} \mathrm{Baru} \mathrm{Km} 19$ hingga Km 20 dan di Pasir Putih Kebupaten Kampar. Sedangkan Ciri-ciri ubi kayu yang dipakai dalam pembuatan keripik ubi kayu ini seperti: berumur pendek artinya usia sejak mulai tanam sampai musim panen relatif lebih singkat yaitu berumur 5-8 bulan dan tidak banyak terdapat kebusukan pada ubi kayu tersebut.

2. Pengupasan: ubi kayu yang sudah cukup umur selanjutnya dikupas kulitnya dengan menggunakan pisau. Tebal kulit dibuang sekitar $0,25 \mathrm{~cm}$, ujung buah dibuang 1,5 $\mathrm{cm}$ dan pangkalnya dibuang sekitar $1 \mathrm{~cm}$.

3. Pencucian: setelah di kupas lalu di cuci dengan air bersih dan direndam sekitar 5 menit.
4. Pengirisan: ubi yang sudah dicuci bersih lalu diiris dengan menggunakan ketam atau pemotong tipis-tipis sehingga berbentuk bulat lingkaran.

5. Pengorengan: penggorengan dilakukan dengan menggunakan kompor yang terbuat dari semen dan batu bata serta berbahan bakar kayu.

6. Pengeringan: setelah masak keripik ubi dikeringkan dengan menggunakan niru atau pengeringan secara manual.

7. Pemberian rasa: setelah keripik ubi kayu dikeringkan selanjutnya dilakukan pemberian rasa pada keripik ubi kayu seperti rasa penyedap asin, manis, pedas dan lainnya. Rasa tersebut diberikan untuk memberikan rasa yang bervariasi agar lebih enak dan gurih.

8. Pengemasan: pengemasan dilakukan dengan menggunakan plastik dalam dan plastik luar. Plastik dalam berukuran $11 \times 12$ $\mathrm{cm}$ dan plastik luar berukuran $35 \times 55 \mathrm{~cm}$ dan dilem dengan lampu semprong dan ada juga yang telah menggunakan alat perekat yang cara kerjanya hanya ditekan. Didalam pengemasan pengusaha keripik ubi kayu juga mencantumkan merek produk atau nama produk keripik ubi mereka, alamat, No sertifikat aman dari Dinas Kesehatan untuk menarik minat pembeli.

\section{Tingkat Partisipasi Kerja (TPK) Tenaga Kerja Wanita di Kelurahan Kulim}

Tingkat partisipasi kerja adalah persentase jumlah angkatan kerja yang mempunyai pekerjaan (Suroto, 1992). TPK tenaga kerja wanita di Kelurahan Kulim Kecamatan Tenayan Raya, dapat dihitung dengan cara membandingkan jumlah tenaga kerja wanita yang bekerja pada usaha keripik ubi kayu di Kelurahan Kulim Kecamatan Tenayan Raya dengan Jumlah angkatan kerja di Kelurahan Kulim dikalikan $100 \%$.

Jumlah tenaga kerja wanita yang bekerja pada usaha keripik ubi kayu di Kelurahan Kulim sebanyak 113 orang. Sedangkan jumlah angkatan kerja wanita di Kelurahan Kulim sebanyak 7.452 orang . Nilai angkatan kerja ini didapat dari jumlah penduduk wanita di Kelurahan Kulim Kecamatan Tenayan Raya yang berumur produktif (15-59 Tahun). Hasil perhitungan nilai TPK tenaga kerja wanita pada 
usaha keripik ubi kayu di Kelurahan Kulim sebesar 1,52\%. Angka ini berarti dari setiap 100 orang penduduk wanita usia produktif di Kelurahan Kulim Kecamatan Tenayan Raya terdapat 1-2 wanita yang bekerja pada usaha keripik ubi kayu.

\section{Kontribusi Tenaga Kerja Wanita pada Usaha Keripik Ubi Kayu Terhadap Pendapatan Rumah Tangga}

Kontribusi pendapatan adalah sumbangan nilai hasil yang diterima sebagai imbalan dari anggota rumah tangga yang bekerja. Untuk mengetahui kontribusi tenaga kerja wanita diperhitungkan berdasarkan perbandingan antara pendapatan rumah tangga dari kerja di luar rumah dengan pendapatan total rumah tangga. Pendapatan rumah tangga di luar pendapatan tenaga kerja wanita dari usaha keripik ubi kayu ini yaitu dari pendapatan suami. Selanjutnya untuk mengetahui lebih jelas kotribusi tenaga kerja wanita terhadap pendapatan keluarga disajikan pada Tabel 1.

Kontribusi total pendapatan rumah tangga ini berasal dari pendapatan suami dan istri. Kontribusi pendapatan tenaga kerja wanita dari usaha keripik ubi kayu di Kelurahan Kulim Kecamatan Tenayan Raya adalah $33,37 \%$ dan $66,63 \%$ merupakan kontribusi pendapatan rumah tangga selain pendapatan tenaga kerja wanita dari usaha keripik ubi kayu.

\section{Analisis Faktor-Faktor yang Mempengaruhi Partisipasi Tenaga Kerja Wanita Pada Usaha Keripik Ubi Kayu di Kelurahan Kulim}

Untuk mengestimasi fungsi partisipasi tenaga kerja wanita pada usaha keripik ubi kayu di Kelurahan Kulim Kecamatan Tenayan Raya sekaligus untuk mengetahui hubungan antara partisipasi dengan faktor-faktor yang diduga mempengaruhinya dengan menggunakan metode regresi linier berganda dengan bantuan SPSS 17. Berdasarkan output dari program tersebut dibentuk fungsi regresi faktor-faktor yang mempengaruhi partisipasi tenaga kerja wanita pada usaha keripik ubi kayu dapat dilihat pada Tabel 2.

Pada Tabel 2 diperoleh persamaan regresi terhadap partisipasi yang diberikan tenaga kerja wanita pada usaha keripik ubi kayu yaitu dapat dilihat sebagai berikut:

$$
\begin{aligned}
Y= & -1,539-0,076 X_{1}+0,036 X_{2}+0,068 X_{3}+ \\
& 0,020 X_{4}+0,362 X_{5}+0,082 X_{6}
\end{aligned}
$$

Secara simultan didapat $\mathrm{F}$ hitungnya yaitu sebesar 17,208 sehingga dengan begitu pada penelitian ini secara bersama-sama faktor-faktor tersebut mempengaruhi partisipasi tenaga kerja wanita pada usaha keripik ubi kayu. Nilai koefesien determinasi adjusted $R$ square $\left(\mathrm{R}^{2}\right)$ sebesar 0,752 atau $75,20 \%$. Artinya, bahwa $75,20 \%$ partisipasi tenaga kerja wanita pada usaha keripik ubi kayu ditentukan oleh faktor umur, faktor pendidikan, faktor pengalaman bekerja, faktor jumlah tanggungan keluarga, faktor upah dan faktor total pendapatan keluarga. Sedangkan sisanya yaitu 24,80\% ditentukan oleh faktor lain yang tidak termasuk dalam model seperti faktor budaya, hobby dan lain-lain.

Sedangkan secara parsial berdasarkan uji t, adalah faktor umur, faktor pengalaman bekerja dan faktor upah yang berpengaruh nyata pada tingkat kepercayaan 90\% dan 95\%. Lebih jelasnya diuraikan berikut :

Tabel 1. Kontribusi Tenaga Kerja Wanita pada Usaha Keripik Ubi Kayu Terhadap Pendapatan

\begin{tabular}{|c|c|c|}
\hline No & Uraian & Rata-Rata \\
\hline 1 & Pendapatan tenaga kerja wanita di usaha keripik ubi kayu (Rp/bln) & $1.132 .363,64$ \\
\hline 2 & Pendapatan suami (Rp/bln) & $2.260 .606,06$ \\
\hline 3 & Total pendapatan rumah tangga (Rp/bln) & $3.392 .969,70$ \\
\hline \multirow[t]{3}{*}{4} & Kontribusi pendapatan & \\
\hline & a. Tenaga kerja wanita dari usaha keripik ubi kayu (\%) & 33,37 \\
\hline & $\begin{array}{l}\text { b. Total pendapatan rumah tangga selain upah tenaga kerja wanita dari } \\
\text { usaha keripik ubi kayu (\%) }\end{array}$ & 66,63 \\
\hline
\end{tabular}
Rumah Tangga di Kelurahan Kulim Kecamatan Tenayan Raya, Tahun 2016 
Tabel 2. Koefesien Regresi Faktor-Faktor yang Mempengaruhi Partisipasi Tenaga Kerja Wanita pada Usaha Keripik Ubi Kayu di Kelurahan Kulim Kecamatan Tenayan Raya, Tahun 2016

\begin{tabular}{|c|c|c|c|}
\hline \multirow{2}{*}{ No } & \multirow{2}{*}{ Indevendent Variabel (X) } & \multicolumn{2}{|c|}{ Nilai Koefesien } \\
\hline & & Koefesien & Signifikan \\
\hline 1 & Constanta /Intercept (Xi) & $-1,539$ & 0,470 \\
\hline 2 & Ln Umur (X1) & $-0,076$ & $0,015 * *$ \\
\hline 3 & Ln Pendidikan (X2) & 0,036 & 0,117 \\
\hline 4 & Ln Pengalaman Bekerja (X3) & 0,068 & $0,063 *$ \\
\hline 5 & Ln Jumlah Tanggungan Keluarga (X4) & 0,020 & 0,270 \\
\hline 6 & Ln Upah (X5) & 0,362 & $0,026 * *$ \\
\hline 7 & Ln Total Pendapatan Keluarga (X6) & 0,082 & 0,319 \\
\hline 8 & F Hitung & 17,208 & $0,000^{\mathrm{a}}$ \\
\hline 9 & Adj.R Square & \multicolumn{2}{|c|}{0,752} \\
\hline
\end{tabular}

Keterangan: $* *=$ signifikan pada tingkat kepercayaan $95 \%(0,05)$

$*$ = signifikan pada tingkat kepercayaan $90 \%(0,10)$

\section{Pengaruh Faktor Umur (X1) Terhadap Partisipasi Tenaga Kerja Wanita (Y)}

Besarnya pengaruh umur terhadap partisipasi tenaga kerja wanita pada usaha keripik ubi kayu ditentukan oleh koefesien regresi $\left(b_{1}\right)$ yaitu sebesar $-0,076$ artinya umur tenaga kerja wanita berpengaruh nyata dan setiap peningkatan 1 tahun pada tenaga kerja wanita makan akan menurunkan nilai partisipasi tenaga kerja wanita sebesar $-0,076 \%$. Tanda negatif menunjukkan bahwa variabel umur berbanding terbalik dengan persamaan pertisipasi tenaga kerja wanita dan signifikannya kecil dari pada 0,05 sehingga tinggkat kepercayaannya mencapai $95 \%$ hal ini menunjukkan bahwa faktor umur berpengaruh nyata dan juga berarti semakin meningkat umur tenaga kerja wanita maka semakin menurun pula partisipasi yang diberikan tenaga kerja wanita terhadap usaha keripik ubi kayu di Kelurahan Kulim Kecamatan Tenayan Raya.

\section{Pengaruh Faktor Pengalaman Bekerja (X3) Terhadap Partisipasi Tenaga Kerja Wanita (Y)}

Besarnya pengaruh pengalaman bekerja dapat ditentukan oleh koefesien (b3) sebesar 0,068 yang berarti setiap peningkatan 1 tahun pengalaman bekerja tenaga kerja wanita pada usaha keripik ubi kayu maka akan meningkatkan nilai partisipasi tenaga kerja wanita sebesar $0,068 \%$. Tanda positif menunjukkan bahwa variabel pengalaman bekerja berbanding lurus dengan partisipasi tenaga kerja wanita dan signifikannya kecil dari 0,10 sehingga mencapai tingkat kepercayaan $90 \%$ hal ini menunjukkan bahwa faktor pengalaman bekerja berpengaruh nyata. Hal ini juga berarti semakin tinggi tingkat pengalaman bekerja tenaga kerja wanita pada usaha keripik ubi kayu maka akan miningkatkan partisipasi yang diberikan tenaga kerja wanita tersebut terhadap usaha keripik ubi kayu di Kelurahan Kulim Kecamatan Tenayan Raya.

\section{Pengaruh Faktor Upah (X5) Terhadap Partisipasi Tenaga Kerja Wanita (Y)}

Besarnya pengaruh upah dapat ditentukan oleh koefesien regresi $\left(b_{5}\right)$ sebesar 0,362 yang artinya setiap peningkatan upah tenaga kerja wanita pada usaha keripik ubi kayu sebesar $\mathrm{Rp}$ 1 perbulannya maka akan terjadi peningkatan partisipasi tenaga kerja wanita terhadap usaha keripik ubi kayu sebesar $0,362 \%$. Tanda positif menunjukan bahwa variabel upah berbanding lurus dengan partisipasi tenaga kerja wanita dan signifikannya kecil dari 0,05 sehingga mencapai tingkat kepercayaan 95\% hal ini menunjukkan bahwa faktor upah berpengaruh nyata. Hal ini juga berarti semakin tinggi tingkat upah yang didapat seorang tenaga kerja wanita pada usaha keripik ubi kayu maka akan meningkatkan partisipasi yang diberikan tenaga kerja wanita tersebut terhadap usaha keripik ubi kayu. 
Berdasarkan uji F-hitung dan t-hitung, maka Ha diterima Ho ditolak karena terdapat pengaruh nyata faktor-faktor umur, tingkat pendidikan, pengalaman bekerja, jumlah tanggungan keluarga, upah dan total pendapatan keluarga terhadap partisipasi tenaga kerja wanita. Selanjutnya, untuk memperoleh nilai perkiraan yang tidak bias dan efesien dari persamaan regresi linear berganda, maka dalam pelaksanaan analisis data harus memenuhi asumsi-asumsi klasik. Untuk dapat memenuhi asumsi tersebut, dilakukan beberapa uji parameter yang dianggap cukup berpengaruh terhadap hasil regresi yaitu:

\section{Uji Multikolinearitas}

Untuk mendeteksi adanya multikolinearitas dapat dilihat dari value inflation factor (VIF) dan tolerance. Apabila VIF hitung lebih kecil dari pada 5 dan angka tolerance hitung lebih besar dari pada 5\% maka tidak akan terjadi multikolenearitas. Dari hasil Collinearity Statistics dari variabel secara berturut-turut terdapat nilai VIF faktor umur sebesar 1,630 serta nilai Tolerancenya sebesar $61,30 \%$, nilai VIF faktor pendidikan sebesar 1,107 serta nilai Tolerancenya sebesar $90,40 \%$, nilai VIF faktor pengalaman bekerja sebesar 4,399 serta nilai Tolerancenya sebesar $22,70 \%$, nilai VIF faktor tanggungan keluarga sebesar 1,126 serta nilai Tolerancenya sebesar $88,80 \%$, nilai VIF faktor upah sebesar 4,610 serta nilai Tolerancenya sebesar $21,70 \%$ dan nilai VIF faktor total pendapatan rumah tangga sebesar 1,612 serta Tolerancenya sebesar $62,00 \%$. Berdasarkan hasil uji multikolenearitas pada Collinearity Statistics menunjukkan nilai VIF (value inflation factor) masing-masing variabel berada dibawah angka 5 dan nilai tolerance lebih besar dari pada 5\% atau 0,05. Dengan demikian dapat disimpulkan bahwa secara keseluruhan variabel yang digunakan dalam penelitian ini tidak terjadi multikolinearitas.

\section{Uji Autokorelasi}

Uji autokorelasi yang digunakan adalah uji durbin-watson. Menurut santoso (2002). Kreteria uji durbin-watson ialah apabila DW < 2 berarti ada autokorelasi positif, $-2<\mathrm{DW}<+2$ artinya tidak ada autokorelasi dan juga apabila DW $>+2$ berarti ada autokorelasi negatif. Hasil Durbin-Watson sebesar 1,544.Berdasarkan nilai
Durbin-Watson yang didapat berada diantara + 2 dan -2 , yaitu $-2<1.544<+2$. Berarti dapat disimpulkan bahwa tidak terjadi autokorelasi dimana gangguan pada suatu observasi tidak berkorelasi dengan gangguan observasi yang lain.

\section{Uji Heteroskedastisitas}

Untuk mendeteksi ada atau tidaknya heteroskedastisitas ragam, dalam pengujian ini bisa dilihat dari pola yang berbentuk pada titiktitik pada grafik scaterplot. Berdasarkan hasil uji grafik scatterplot tersebut menunjukkan titiktitik membentuk pola tertentu dan titik-titik menyebar dari ujung bawah kiri keujung atas kanan dan dapat ditarik kesimpulan bahwa terjadi heteroskedastisitas.

\section{Uji Normalitas}

Untuk mendeteksi apakah dalam model regresi variabel terikat dan variabel bebas keduanya mempunyai distribusi normal ataukah tidak. Berdasarkan hasil uji grafik pola normal probability plot tersebut menunjukkan titik-titik membentuk satu garis lurus diagonal. Sehingga dapat ditarik kesimpulan bahwa distribusi data normal karena penyebaran data mengikuti garis normal.

\section{KESIMPULAN DAN SARAN}

\section{Kesimpulan}

1. Karakteristik tenaga kerja wanita pada usaha keripik ubi kayu di Kelurahan Kulim Kecamatan Tenayan Raya rata-rata berumur 33 tahun, berpendidikan 9 tahun, berpengalaman 3 tahun dan mempunyai jumlah tanggungan keluarga sebanyak 4 orang.

2. Tingkat Partisipasi Kerja (TPK) tenaga kerja wanita pada usaha keripik ubi kayu di Kelurahan Kulim Kecamatan Tenayan Raya sebesar $1,52 \%$ yang berarti dari 100 orang penduduk wanita usia kerja di Kelurahan Kulim Kecamatan Tenayan Raya terdapat 12 orang wanita yang bekerja pada usaha keripik ubi kayu.

3. Kontribusi pendapatan tenaga kerja wanita pada usaha keripik ubi kayu di Kelurahan Kulim Kecamatan Tenayan Raya terhadap pendapatan total rumah tangga rata-rata sebesar $33,37 \%$. 
4. Umur, tingkat pendidikan, pengalaman bekerja, jumlah tanggungan keluarga, upah dan total pendapatan keluarga secara simultan berpengaruh terhadap partisipasi tenaga kerja wanita pada usaha keripik ubi kayu, sedangkan secara parsial variabel yang berpengaruh nyata terhadap partisipasi tenaga kerja wanita adalah faktor umur, faktor pengalaman bekerja dan faktor upah tenaga kerja wanita pada usaha keripik ubi kayu di Kelurahan Kulim Kecamatan Tenayan Raya.

\section{Saran}

1. Sebagai upaya peningkatan partisipasi tenaga kerja wanita pada usaha keripik ubi kayu, sebaiknya pengusaha keripik ubi kayu di Kelurahan Kulim Kecamatan Tenayan Raya melakukan perbaikkan upah pada para pekerjanya dan terus memperkerjakan tenaga kerja wanita dengan umur yang masih produktif.

2. Sebagai upaya pengembangan usaha keripik ubi kayu, sebaiknya pemerintah daerah memberikan modal/bantuan pada pengusaha keripik ubi kayu karena usaha keripik ubi kayu ini berperan dalam penyerapan tenaga kerja wanita sehingga dapat mengurangi tingkat pengangguran, terutama wanita yang sudah menjadi angkatan kerja dan berusia produktif.

\section{DAFTAR PUSTAKA}

Badan Pusat Statistik Provinsi Riau. 2015. Riau Dalam Angka Tahun 2014. Pekanbaru.

Bakce, D. PERILAKU KONSUMSI PANGAN POKOK OLEH RUMAHTANGGA DI PROVINSI RIAU.

Gujarati, D. 1999. Ekonomi Dasar. Terjemahan Sumarno Zain. Cetakan Keenam. Erlangga. Jakarta.

Heriyanto, H. (2016). Perilaku Konsumsi

Pangan Sumber Karbohidrat

Rumahtangga Petani Kelapa Sawit Di

Kecamatan Kandis Kabupaten Siak.

Jurnal Ilmiah Pertanian, 13(1), 22-30.

Muhammad. 2011. Ekonometrika Suatu Pendekatan Aplikatif. Bumi Aksara, Jakarta

Sudjana. 2001. Metoda Statistika. Edisi Kelima. Tarsito, Bandung.
Sarwono. 2006. Metode Penelitian Kuantitatif dan Kualitatif. Graha Ilmu, Yogyakarta.

Suparmoko. 1993. Pengantar Ekonomi Mikro. Bpee. Yogyakarta.

Sugiyono H. 2009. Metode Penelitian Kuantitatif, Kualitatif, dan R\&D. Alfabeta, Bandung.

Sudjana. 2001. Metoda Statistika. Edisi Kelima. Tarsito, Bandung.

Sukiyono, K dan Sriyoto. 1997. Transformasi Struktural Wanita Transmigran dan Kontribusinya Terhadap Pendapatan Rumah Tangga : Kasus di Daerah Transmigrasi Kotamadya Bengkulu. Jurnal Agro Ekonomi 16 (1) : 1 - 16.

Simanjuntak, P.J. 1985. Pengantar Ekonomi Sumber Daya Manusia. Jakarta: FEUI (Fakultas Ekonomi Universitas Indonesia), Jakarta.

Sinuraya. 1995. Dasar-Dasar Biokimia Untuk Pertanian. Usu-Press, Medan 